\title{
Keterampilan Berpikir Kritis melalui Penerapan Model Pembelajaran Inkuiri Terbimbing di Kelas XI IPA
}

\author{
Ana Rizka Falentina ${ }^{1}$, Murni Saptasari ${ }^{1}$, Sri Endah Indriwati ${ }^{1}$ \\ ${ }^{1}$ Pendidikan Biologi-Universitas Negeri Malang
}

\begin{tabular}{l} 
INFO ARTIKEL \\
\hline Riwayat Artikel: \\
Diterima: 09-01-2019 \\
Disetujui: $14-10-2020$ \\
\hline
\end{tabular}

\section{Kata kunci:}

critical thinking; guided inquiry; high school student; berpikir kritis; inkuiri terbimbing; siswa SMA

\begin{abstract}
ABSTRAK
Abstract: Education aims to prepare students to become independent generations who are able to face the challenges of the times by having 21 st century life skills, one of which is critical thinking, in fact contrary to the low critical thinking skills that occur in SMAN 2 Probolinggo. The purpose of this study was to describe the application of guided inquiry learning in improving critical thinking skills. This type of research is Class Action Research (CAR). Data is analyzed by triangulation through the process of data reduction, data presentation, and conclusion drawing. Research Results guided inquiry learning model can change the way students learn to practice high-level thinking through learning syntax so that it gives the impact of increasing critical thinking skills by $18.75 \%$ students of class XI IPA 1 Probolinggo 2 High School.
\end{abstract}

\begin{abstract}
Abstrak: Pendidikan bertujuan menyiapkan siswa menjadi generasi mandiri yang mampu menghadapi tantangan zaman dengan memiliki keterampilan hidup abad 21 salah satunya berpikir kritis, faktanya bertolak belakang dengan rendahnya keterampilan berpikir kritis yang terjadi di SMAN 2 Probolinggo. Tujuan penelitian ini adalah mendeskripsikan penerapan pembelajaran inkuiri terbimbing dalam meningkatkan keterampilan berpikir kritis. Jenis penelitian ini adalah Penelitian Tindakan Kelas. Data dianalisis secara triangulasi melalui proses reduksi data, penyajian data, dan penarikan kesimpulan. Hasil Penelitian model pembelajaran inkuiri terbimbing dapat mengubah cara belajar siswa untuk berlatih berpikir tingkat tinggi melalui sintaks pembelajaran sehingga memberikan dampak meningkatkan keterampilan berpikir kritis sebesar $18,75 \%$ siswa kelas XI IPA 1 SMA Negeri 2 Probolinggo.
\end{abstract}

\author{
Alamat Korespondensi: \\ Ana Rizka Falentina \\ Pendidikan Biologi \\ Universitas Negeri Malang \\ Jalan Semarang 5 Malang \\ E-mail:annrizka8@gmail.com
}

Pendidikan diarahkan menuju pendekatan konstruktivis ke arah student center memasuki abad 21 (Perdani, Santosa, Ramli, \& Martono, 2015). Bergesernya paradigma menuju student centered mempengaruhi berubahnya kurikulum yang menuntut siswa menguasai kecakapan hidup abad 21 (BNSP, 2010). Kecakapan hidup abad 21 meliputi keterampilan komunikasi, kolaboratif, berpikir kreatif, dan berpikir kritis dapat dikembangkan melalui perbaikan proses pembelajaran (Permendikbud 20, 2016). Keterampilan berpikir kritis melatih siswa memecahkan masalah kehidupan di era global (Danisa \& Dwiastuti, 2016). Guru mengajak siswa beperan aktif dan efektif mengkonstruk pengetahuan sendiri kemudian menerapkannya dalam pemecahan masalah yang dihadapi melalui pemikiran kritis (William, 2010). Pengembangan berpikir kritis di kelas sebagai dasar pengembangan proses berpikir (Duron, Limbach, \& Waugh, 2006). Proses berpikir memerlukan peran guru dalam mengembangkan model pembelajaran yang tepat (Joyce. \& Shower., 2009). Guru dituntut mampu mengembangkan student centered learning (Natalina, Mahadi, \& Suzane, 2013) untuk melatih siswa menyelesaikan masalah melalui keterampilan berpikir (Nurroyani, Dwiastuti, \& Karyanto, 2015) sehingga kecakapan hidup abad 21 merekat pada diri siswa (Masitoh \& Ariyanto, 2017).

Data hasil observasi proses pembelajaran yang dilakukan di Kelas X MIA 1 SMA Negeri 2 Probolinggo tahun ajaran 2017/2018 pada materi perubahan lingkungan menunjukkan guru belum banyak memberdayakan pengembangan keterampilan berpikir kritis siswa pada pelaksanan kegiatan pembelajaran. Proses pembelajaran terjadi secara satu arah. Proses pembelajaran hanya terjadi transfer ilmu dari guru ke siswa. Siswa layaknya wayang yang mengikuti instruksi guru. Pada saat mengerjakan tes, siswa hanya menyalin jawaban dari buku paket tanpa melalui proses berpikir yang mendalam. 
Hasil observasi mendeskripsikan rendahnya kemampuan berpikir kritis dialami oleh siswa kelas X IPA 1 SMA Negeri 2 Probolinggo. Rendahnya kemampuan berpikir kritis dilihat dari kemampuan (1) memfokuskan pertanyaan, (2) berargumentasi, (3) mendeduksi, (4) menginduksi, dan (5) mengevaluasi (Zubaidah, 2017). Permasalahan rendahnya berpikir kritis dapat diatasi melalui pengimplementasian model pembelajaran inkuiri terbimbing (Rahmah, Lesmanawati, \& Wahidin, 2015). Inkuiri terbimbing merupakan salah satu pembelajaran yang dapat memberikan pelatihan keterampilan berpikir kritis (Kuhlthau, 2010). Inkuiri terbimbing mengembangkan berpikir kritis melalui pertanyaan berlandaskan keingintahuan (Andrini, 2016), memfasilitasi sikap rasa ingin tahu terhadap fenomena dengan pemberian makna dan mempersiapkan pembelajaran sepanjang hayat (Sanjaya, 2007). Keterlibtan secara aktif siswa dalam proses pembelajaran melalui perancangan dan penginvestigasian, kemudian melakukan kegiatan penganalisisan hasil diinvestigasi, (Kuhlthau, 2010).

Inkuiri terbimbing sesuai dengan karakter ilmu Biologi yang mempelajari makhluk hidup dan lingkungannya (Campbell \& Reece, 2002), serta gejala alam yang teramati dengan indra (Retnosari, 2016). Pembelajaran inkuiri terbimbing menekankan pada eksperimen (Bilgin, 2009), melibatkan semaksimal mungkin kemampuan siswa untuk melakukan penyelidikan secara sistematis, kritis (Kevin, 2004) logis dan analitis (Julianto, 2011) sesuai dengan karakteristik ilmu Biologi sebagai salah satu ilmu sains yang menggunakan langkah metode ilmiah, sistematis, logis dan analitis dalam memecahkan masalah (Campbell \& Reece, 2002). Langkah metode ilmiah yang meliputi merumuskan masalah, mengumpulkan data, menyusun hipotesis, penelitian untuk membuktikan hipotesis, menganalaisis data, membuat kesimpulan dan mempubilikasikan hasil selaras dengan langkah inkuiri terbimbing. Tahapan inkuiri terbimbing meliputi: (1) mengeksplorasi fenomena, (2) memfokuskan pertanyaan, (3) merancang investigasi, (4) mengadakan investigasi, (5) menganalisis data, (6) mengkonstruk pengetahuan baru dan (7) mengkomunikasikan pengetahuan baru (llewellyn, 2013).

Inkuiri terbimbing tepat diterapkan pada jenjang Sekolah Menengah Atas. Hal ini didukung oleh Llewellyn (2011) mengungkapkan inkuiri terbimbing merupakan level inkuiri yang bertujuan untuk menyiapkan pengalaman dasar penelitian. Pembelajaran inkuiri terbimbing menekankan kegiatan siswa merancang penelitian dengan melibatkan kelompok melalui bimbingan guru untuk membangun konsep sains. Dengan bimbingan guru, konsep sains yang terbangun lebih terarah sesuai indikator yang dicapai (Minner, 2009).

\section{METODE}

Pendekatan pada penelitian yang dilakukan adalah kualitatif dengan jenis penelitian tindakan kelas. PTK bertujuan untuk menyelesaikan permasalahan rendahnya keterampilan berpikir kritis dengan menggunakan model pembelajaran inkuiri terbimbing. Kehadiran peneliti sangat penting sebagai perencana, pelaksana, pengumpul data, penganalisis data dan pelapor hasil penelitian. Penelitian ini terdiri atas beberapa tahapan, yakni (1) observasi awal untuk mengidentifikasi permasalahan; (2) perencanaan pembelajaran untuk memperbaiki permasalahan dalam pembelajaran; (3) pelaksanaan tindakan; (4) pengumpulan data penelitian; (5) analisis data; (6) pelaporan hasil penelitian.

Subjek dari penelitian merupakan siswa dari kelas XI IPA 1 SMAN 2 Probolinggo tahun pelajaran 2018/2019. Data yang dikumpulkan dalam penelitian meliputi hasil observasi keterlaksanaan pembelajaran guru siswa dan hasil tes keterampilan berpikir kritis. Sumber data berasal dari seluruh siswa kelas XI IPA1 SMAN 2 Probolinggo sebanyak 32 siswa, tiga observer, dan guru model. Analisis data dilakukan secara kuantitatif dan kualitatif. Analisis data secara kuantitatif diperoleh dari data observasi keterlaksanaan pembelajaran dan penilaian keterampilan berpikir kritis. Data dianalisis melalui tiga tahap yaitu reduksi data, penyajian data, dan penarikan kesimpulan. Data keterampilan berpikir kritis dan keterlaksanaan pembelajaran disajikan dan ditafsirkan kemudian ditarik kesimpulan.

\section{HASIL \\ Paparan Data Siklus I \\ Perencanaan Tindakan Siklus I}

Hasil pengkajian refleksi hasil observasi awal, peneliti memberikan solusi terhadap rendahnya keterampilan berpikir kritis siswa dengan menerapkan model pembelajaran inkuiri terbimbing. Adapun langkah perencanaan tindakan sebagai berikut: (a) penyusunan silabus yang memuat penilaian berpikir kritis dengan sintaks inkuiri terbimbing, (b) penyusunan Rencana Pelaksanaan Pembelajaran (RPP), lembar kegiatan siswa, lembar observasi keterlaksanaan pembelajaran, kisi-kisi, rubrik, soal berpikir kritis.

\section{Hasil Observasi Tindakan Siklus I Keterlaksanaan Pembelajaran Model Inkuiri Terbimbing}

Pelaksanaan tindakan siklus I pada materi struktur jaringan tumbuhan dimulai dengan tahap mengeksplorasi fenomena menggulungnya daun jagung kemudian memfokuskan pertanyaan terkait fenomena dengan menginduksi pertanyaan khusus menjadi pertanyaan bersifat umum yaitu bagaimana keterkaitan struktur dan fungsi jaringan dengan fungsi organ yang disusunnya. Kemudian siswa merancang investigasi dengan mengumpulkan informasi yang relevan dengan bantuan mind map. 
Pada kegiatan penelitian dan investigasi, siswa kesulitan dalam membuat preparat irisan melintang daun jagung. Guru memotivasi siswa untuk membuat preparat terbaik untuk menemukan objek yang paling jelas teridentifikasi. Siswa mengidentifikasi karakteristik jaringan berdasarkan investigasi literatur. Selanjutnya, siswa menganalisis, menafsirkan, dan memaknai data yang diperoleh melaui proses induksi dan deduksi data jenis jaringan pada masing masing organ tumbuhan. Siswa bekerjasama menyusun argumen disertai bukti pendukung dari pengetahuan baru yang ditemukan. Siswa mengevaluasi dan membuat makna dari pengetahuan baru yang diperoleh kemudian menghubungkan pengetahuan baru dan pengetahuan sebelumnya di bawah bimbingan guru. Siswa mempresentasikan dan mengkomunikasikan hasil pengamatan dan diskusi di depan kelas dalam bentuk PPT. Dalam kegiatan presentasi kelompok, indikator berpikir kritis memberikan argumen, melakukan deduksi dan induksi berkembang pada siswa diri siswa. Tanggapan dan sanggahan kepada penyaji dari kelompok lain disertai argumen pendukung mampu mengembangkan indikator mengevaluasi pengetahuan baru yang dikomunikasikan.

Pelaksanaan tahap-tahap pembelajaran yang diterapkan oleh peneliti diobservasi dengan menggunakan lembar observasi. Keterlaksanaan pembelajaran perlu diukur agar diperoleh data tentang konsistensi peneliti dalam melaksanakan rencana pembelajaran yang telah disusun berdasarkan sintaks model pembelajaran inkuiri terbimbing. Observasi keterlaksanaan pembelajaran dilaksanakan oleh para observer pada setiap pertemuan. Tabel 1 menyajikan ringkasan data hasil observasi keterlaksanaan pembelajaran selama siklus I.

Keterlaksanaan pembelajaran oleh guru dengan model inkuiri terbimbing sebesar 88,78\%. Data tersebut menunjukkan bahwa rata-rata pelaksanaan pembelajaran model inkuiri terbimbing berada pada kategori sangat baik, memberikan makna pelaksanaan langkah-langkah pembelajaran sudah dilaksanakan sesuai dengan yang telah direncanakan dalam RPP. Namun masih perlu perbaikan dalam hal managemen waktu terutama pada tahap mengkomunikasikan hasil penemuan baru. Tahap ini meleset dari rencana pembelajaran yang seharusnya selesai dalam satu kali pertemuan, harus selesai dalam dua kali pertemuan. Dilakukan pula observasi keterlaksanaan pembelajaran inkuiri terbimbing yang dilakukan oleh siswa. Keterlaksanaan pembelajaran oleh siswa perlu diukur agar diperoleh data tentang kegiatan siswa dalam pelaksanaan rencana pembelajaran yang telah disusun berdasarkan sintaks model pembelajaran inkuiri terbimbing. Observasi keterlaksanaan pembelajaran dilaksanakan oleh para observer pada setiap pertemuan.

Keterlaksanaan pembelajaran siswa melalui penerapan sintaks model inkuiri terbimbing sebesar 87,69\%. Data ini memberikan informasi bahwa pelaksanaan pembelajaran model inkuiri terbimbing berada pada kategori sangat baik. Kegiatan siswa merupakan respon dari langkah-langkah pembelajaran yang dikembangkan oleh guru. Dari hasil catatan lapangan, indikator keterampilan berpikir kritis siswa masih perlu dikembangkan.

\section{Hasil Berpikir Kritis Siswa Siklus I}

Nilai keterampilan berpikir kritis siswa diperoleh dari hasil tes tulis dengan soal berbentuk uraian. Seluruh indikator yang diukur oleh peneliti pada siklus I yaitu fokus masalah, argumentasi, melakukan induksi melakukan deduksi dan evaluasi yang berada pada kategori siswa kritis. Rata-rata nilai keterampilan berpikir kritis siswa pada siklus I untuk semua indikator sebesar 74,92\%, sedangkan kriteria ketuntasan minimal berpikir kritis secara individual adalah 75\%. Hal tersebut dapat dimaknai keterampilan berpikir kritis siswa masih berada di bawah KKM. Merujuk kepada indikator keberhasilan ketrampilan berpikir kritis secara klasikal yaitu dikatakan berhasil apabila $\geq 75 \%$ siswa dari seluruh siswa yang mengikuti tes mencapai nilai $\geq 75 \%$ belum tercapai. Sebanyak 22 siswa $(68,75 \%)$ siswa yang memperoleh nilai $\geq 75 \%$ dari 32 siswa kelas XI IPA, kemampuan berpikir kritis siswa masih perlu dikembangkann lagi pada siklus berikutnya.

\section{Paparan Data Siklus II \\ Perencanaan Siklus II}

Berdasarkan hasil refleksi siklus I, peneliti merencanakan beberapa tindakan perbaikan yang akan dilaksanakan pada pelaksananaan pembelajaran siklus II. Rencana perbaikan yang akan diterapkan pada siklus II sebagai berikut: (a) lebih memotivasi, membimbing dan melatih siswa untuk mengembangkan keterampilan berpikir kritis (b) memotivasi siswa untuk aktif berdiskusi, bertanya dan berpendapat dalam setiap tahapan pembelajaran dengan memberikan nilai bagi setiap siswa yang berpartisipasi aktif, (c) pada saat membimbing investigasi/penelitian, guru berkeliling ke semua kelompok dan memberikan perhatian lebih kepada siswa yang memiliki keterampilan berpikir kritis rendah, (d) melakukan pengelolaan waktu dengan baik pada setiap tahap pembelajaran, (e) melakukan evaluasi bersama dengan observer seusai pembelajaran agar lebih efektif demi perbaikan pertemuan selanjutnya.

\section{Hasil Tindakan Siklus II}

\section{Keterlaksanaan Pembelajaran Inkuiri Terbimbing}

Pelaksanaan tindakan siklus II pada materi struktur jaringan hewan dimulai dengan tahap mengeksplorasi fenomena jaringan ikat pada tulang ayam. Dari kegiatan pengamatan fenomena, pengajuan berbagai pertanyaan yang merangsang keingintahuan siswa, siswa dapat menemukan fokus permasalahan utama yaitu keterkaitan struktur dengan fungsi organ yang disusun. Guru membimbing siswa merancang investigasi mengumpulkan informasi dibantu dengan pembuatan mind map untuk menjawab permasalahan. Siswa merancang investigasi dengan mengumpulkan informasi relevan untuk menjawab 
permasalahan keterkaitan struktur jaringan dengan fungsi organ yang disusun. Siswa melakukan penelitian tentang struktur epitel pipi untuk menjawab permasalahan. Guru membimbing dan mengarahkan siswa memaknai analisis data hasil penelitian. Siswa menganalisis data hasil investigasi studi literatur dan hasil eksperimen. Siswa menyusun argumen disertai bukti pendukung dari pengetahuan baru yang ditemukan dibawah bimbingan guru. Guru mendampingi siswa dalam mengkomunikasikan hasil pengamatan dan investigasi literatur. Siswa lain memberikan respon sebagai evaluasi dan argumen terhadap hasil laporan penyaji.

Pelaksanaan pembelajaran diobservasi oleh tiga observer dengan instrumen lembar observasi. Keterlaksanaan pembelajaran perlu diukur untuk memperoleh data konsistensi peneliti dalam melaksanakan rencana pembelajaran yang telah disusun berdasarkan sintaks model inkuiri terbimbing. Observasi keterlaksanaan pembelajaran dilaksanakan oleh para observer pada setiap pertemuan. Keterlaksanaan sintaks pembelajaran model inkuiri terbimbing oleh guru menunjukkan angka 96,12\%. Dapat ditarik kesimpulan bahwa rata-rata pelaksanaan sintaks pembelajaran model inkuiri terbimbing pada kategori sangat baik. Hal tersebut berarti bahwa pelaksanaan langkah-langkah pembelajaran sudah sesuai dengan perencanaan dalam RPP. Rata-rata keterlaksanaan pembelajaran oleh siswa dengan model inkuiri terbimbing sebesar 97,12\%. Data tersebut menunjukkan bahwa rata-rata pelaksanaan proses pembelajaran model inkuiri terbimbing berada pada kategori sangat baik.

\section{Keterampilan Berpikir Kritis siklus II}

Nilai keterampilan berpikir kritis siswa diperoleh dari hasil tes tulis yang dilaksanakan di akhir siklus II. Nilai rata-rata keterampilan berpikir kritits siswa pada siklus II untuk semua indikator sebesar 84,68 dari kelima indikator berpikir kritis yang diukur oleh peneliti, semua indikator berada pada kategori sangat kritis. Hal tersebut menunjukkan bahwa keterampilan berpikir kritis siswa telah berkembang dengan baik.

Merujuk kepada indikator keberhasilan ketrampilan berpikir kritis secara klasikal yaitu dikatakan berhasil apabila $\geq 75 \%$ siswa dari seluruh siswa yang mengikuti tes mencapai nilai $\geq 75 \%$ sudah tercapai. Dari 32 siswa kelas XI IPA, sebanyak 28 siswa $(87,5 \%)$ siswa yang memperoleh nilai $\geq 75 \%$. Makna dari penafsiran data ini menyatakan keterampilan berpikir kritis siswa sudah berkembang pada siklus II.

\section{Temuan Penelitian}

Data keterampilan berpikir siswa diperoleh dari hasil tes keterampilan berpikir kritis yang dilakukan pada setiap akhir siklus I dan siklus II. Hasil tes siswa dianalisis dengan menggunakan rubrik penilaian berpikir kritis yang telah disusun. Perbandingan nilai kete-rampilan berpikir kritis siswa pada setiap indikator dalam setiap siklus dapat dilihat pada Tabel IX.

Terjadi peningkatan keterampilan berpikir kritis siswa pada setiap indikator, dengan rata-rata nilai keterampilan berpikir kritis pada siklus I sebesar 74,35\% dan rata-rata siklus II sebesar 84,68\% nilai rata-rata keterampilan berpikir kritis siswa pada siklus II telah berkembang.

Data rekapitulasi ketuntasan klasikal keterampilan berpikir kritis siswa pada siklus I dan II memberi makna terjadi peningkatan ketuntasan keterampilan berpikir kritis siswa, dengan nilai ketuntasan berpikir kritis pada siklus I sebesar 68,75\% dan siklus II sebesar $87,5 \%$. Ketuntasan hasil belajarn kognitif siswa pada siklus II telah memenuhi indikator keberhasilan penelitian. Berdasarkan indikator keberhasilan penelitian, penelitian dikatakan berhasil jika $75 \%$ siswa mendapatkan nilai keterampilan berpikir kritis $\geq 75$. Hal ini berarti penerapan model pembelajaran inkuiri terbimbing ber-hasil meningkatkan keterampilan berpikir kritis siswa.

\section{Tabel I. Perbandingan Nilai Indikator Keterampilan Berpikir Kritis Siklus I dan II}

\begin{tabular}{cllll}
\hline No & Indikator & Siklus I & Siklus II & Selisih \\
\hline 1 & Fokus masalah & 78,91 & 85,94 & 7,031 \\
2 & Argumentasi & 74,48 & 89,84 & 15,36 \\
3 & Deduksi & 73,44 & 83,59 & 10,16 \\
4 & Induksi & 76,17 & 82,42 & 6,25 \\
5 & Evaluasi & 68,75 & 81,64 & 12,89 \\
Rata-rata & & 74,35 & 84,68 & 8,07 \\
\hline
\end{tabular}

Data keterampilan berpikir kritis pada siklus II menunjukkan perkembangan pada keseluruhan indikator dengan nilai rata-rata sebesar $84,68 \%$. Hal tersebut menunjukkan bahwa keterampilan berpikir kritis siswa pada setiap indikator berkembang dengan baik. Dari kelima indikator, indikator melakukan argumentasi menunjukkan peningkatan yang paling besar dari siklus I ke siklus II. 


\section{PEMBAHASAN}

Berdasarkan analisis data hasil penelitian, keterampilan berpikir kritis siswa mengalami perkembangan setelah mengikuti pembelajaran dengan model pembelajaran inkuiri terbimbing. Nilai kelima indikator keterampilan berpikir kritis yang diukur dalam penelitian ini yaitu fokus masalah, argumentasi, deduksi, induksi dan evaluasi menunjukkan perubahan ke arah lebih baik dari siklus I ke siklus II.

\section{Fokus Masalah}

Fokus dilakukan oleh siswa pada fase mengeksplorasi fenomena dan memfokuskan pertanyaan. Ketika siswa mengeksplorasi fenomena menggulungnya daun jagung dalam pembelajaran struktur jaringan tumbuhan dan fenomena jaringan tulang ayam serta jaringan otot binaragawan pada struktur materi jaringan hewan, siswa berusaha mengeksplorasi fenomena yang disajikan sehingga muncul rasa ingin tahu dalam bentuk pertanyaan mengapa fenomena ini terjadi.

Rasa ingin tahu dalam mengeksplorasi fenomena jaringan tumbuhan yaitu menggulungnya daun jagung, bagaimana struktur jaringannya sehingga dapat menggulung. Pada materi jaringan hewan fokus eksplorasi yaitu bagaimana struktur jaringan ikat sehingga dapat mengikat dua buah tulang pada kaki ayam, bagaimana struktur otot binaragawan sehingga dapat dipacu membentuk struktur yang padat yang dapat bertahan apabila terus dilatih memotivasi siswa untuk membangun tampilan di otaknya. Sesuai pendapat Ibrahim, Rachmadiarti, \& Nur (2000) rasa ingin tahu anak dimiliki secara alamiah dapat dipacu secara kontinyu untuk memahami dunia di sekitarnya. Apabila siswa selalu ditantang dengan masalah di lingkungannya seperti permasalahan menggulungnya daun jagung, jaringan ikat pada tulang ayam dan jaringan otot pada binaragawan yang nyata dekat dengan lingkungan siswa, maka dapat mengembangkan keterampilan berpikir tingkat tinggi. Hal ini sesuai dengan konsep pemecahan masalah yang merupakan penggabungan konsep lama dengan konsep baru (Lawson, 2000), bukan merupakan keterampilan yang dibawa sejak lahir (Bodner, 1988).

Fokus eksplorasi siswa terletak pada pada bentuk, struktur, dan fungsi jaringan tumbuhan yaitu jaringan pada daun. Eksplorasi pada materi jaringan hewan terfokus jaringan ikat, otot, epitel dan saraf. Siswa memberikan argumen atas hasil observasi fenomena menggulungnya daun jagung tentang koherensi bentuk dan struktur jaringan daun jagung yang diamati siswa. Pada akhirnya, siswa mampu fokus pada suatu titik untuk merumuskan permasalahan dengan menarik hubungan antara dua variabel dalam bentuk pertanyaan, yaitu hubungan keterkaitan struktur, letak dan fungsi jaringan pada daun terhadap fungsi organ daun. Dari tahap mengsplorasi fenomena dan memfokuskan masalah, dapat merubah pencapaian indikator fokus masalah dari $78,9 \%$ pada siklus I menjadi $85,94 \%$ pada siklus II.

\section{Induksi}

Induksi dilakukan oleh siswa pada fase investigasi dan analisis data. Inkuiri terbimbing merupakan model pembelajaran yang diawali merumuskan masalah, menginvestigasi, menganalisis dan menginterpretasikan data yang diakhiri kegiatan penarikan kesimpulan (Chang, Sung, \& Lee, 2003). Penerapan inkuiri terbimbing memberikan dampak diberdayakannya keterampilan siswa dalam menginduksi melalui pemecahan masalah akan mengalami pemeningkatan (Ajwar, Prayitno, \& Sunarno, 2015). Sisa yang terlibat langsung dalm pencarian solusi dan sharing melalui proses diskusi dengan kelompoknya pada fase investigasi memberikan dampak positif bagi pengembangan proses berpikir kritis pada siswa (Tan \& Kim, 2012).

Pada siklus I, siswa melakukan investigasi dengan mengamati struktur jaringan pada daun jagung, daun Rhoeo discolor, batang jagung, dan akar jagung serta preparat awetan struktur akar, batang dan daun sebagai pembanding. Pengumpulan data jaringan diawali dengan mendata jaringan yang bersifat khusus pada setiap organ tumbuhan yaitu jaringan pada daun yang terdiri dari jaringan epidermis, palisade, bunga karang, xilem dan floem. Jaringan pada batang dan akar terdiri atas epidermis, endodermis, korteks, floem dan xilem. Kemudian data tersebut dianalisis melalui kegiatan induksi menjadi data yang bersifat umum yaitu struktur jaringan tumbuhan secara umum yaitu jaringan pelindung, jaringan dasar, jaringan penguat, jaringan pengangkut dan jaringan pelindung. Melalui kegiatan in-vestigasi dan analisis data stuktur dan fungsi jaringan penyusun daun, batang dan akar tumbuhan, siswa terfasilitasi untuk menginduksi data struktur dan fungsi jaringan penyusun organ. Lebih lanjut siswa dapat menganalisis pengetahuan yang bersifat umum mengenai keterkaitan struktur dan fungsi jaringan dalam mendukung fungsi organ

Pada siklus II, keterampilan menginduksi siswa mengalami perkembangan. Siswa mulai terbiasa melakukan kegiatan induksi dari pengalaman siklus I. Siswa menginduksi data struktur, karakteristik dan fungsi jaringan ikat salah satunya tulang dalam mendukung fungsi organ kaki dalam melakukan pergerakan, menginduksi data struktur dan fungsi jaringan epitel trachea dalam mendukung fungsi pernapasan, menginduksi data struktur dan fungsi jaringan otot rangka mendukung fungsi rangka dalam bergerak, otot polos mendukung gerakan pada organ dalam misalnya jaringan pencernaan, otot jantung dengan struktur dan fungsi khusus mendukung pergerakan jantung. Dari data struktur dan fungsi jaringan yang bersifat khusus mendukung fungsi organ tertentu, dapat diinduksi menghasilkan informasi yang bersifat umum yaitu keterkaitan struktur dan fngsi jaringan dalam mendukung organ yang disusunnya. Melalui tahap inkuiri terbimbing, keterampilan melakukan induksi mengalami perkembangan ke arah lebih baik. Diperkuat dengan data analisis kuantitatif yaitu dari 76,17\% pada siklus I menjadi $82.42 \%$ di akhir siklus II. 


\section{Deduksi}

Dalam penyelesaian masalah, diperlukan pula cara berpikir deduktif. Siswa pengumpulkan informasi, data, dan konsep umum terlebih dahulu, pada tahap merancang dan melakukan investigasi, menganalisis data dan menemukan pengetahuan baru, untuk kemudian melakukan pembahasan secara khusus agar dapat digunakan untuk menyusun pemecahan masalah yang telah disusun.

Pada siklus I, tahap merancang investigasi dan investigasi literatur, untuk memecahkan permasalahan keterkaitan struktur dan fungsi jaringan terhadap fungsi organ yang disusun siswa mengumpulkan informasi yang bersifat umum, yaitu karakteristik dan fungsi jaringan secara umum. Kemudian mencari informasi lebih khusus tentang jenis, karakteristik dan fungsi jaringan pada tumbuhan, yaitu jaringan meristem dan jaringan permanen. Jaringan permanen dibagi menjadi jaringan pelindung, jaringan dasar, jaringan penguat, dan jaringan transport. Dilanjutkan dengan informasi terkait struktur dan fungsi jaringan yang terdapat pada daun yaitu jaringan epidermis, palisade, spons, xilem, dan floem. Struktur dan fungsi jaringan pada batang yang meliputi epidermis, endodermis, korteks dan silinder pusat. Struktur dan fungsi jaringan pada akar. Kemudian siswa menganalisis data keterkaitan struktur jaringan daun jagung yang mempengauhi meng-gulungnya daun jagung. Menganalisis keterkaitan struktur dan fungsi jaringan pa-da batang yang mendukung fungsi batang. Serta menganalisis pengaruh struktur dan fungsi jaringan pada akar terhadap fungsi akar.

Pada siklus II, tahap merancang investigasi, investigasi literatur, analisis data dan penemuan pengetahuan baru diawali dengan mengumpulkan informasi terkait jaringan pada hewan secara umum. Kemudian jenis jaringan pada hewan yaitu jaringan epitel, jaringan ikat, jaringan otot dan jaringan saraf. Kemudian masing-masing jaringan tersebut dibagi dalam kelompok jaringan yang lebih khusus. Misalnya jaringan epitel berdasarkan bentuknya dibagi menjadi tiga, yaitu jaringan epitel pipih, kubus, dan silindris. Jaringan ini menurut lapisannya dibagi menjadi dua, yaitu selapis dan berlapis. Data duanalisis secara mendetail tentang struktur, karakteristik, tempat melekat dan fungsi jaringan epitel dalam mendukung fungsi organ yang dilekatinya sampai tersusun pengetahuan baru siswa salah satunya ten-tang keterkaitan struktur dan fungsi jaringan epitel bersilia pada trachea dalam mendukung fungsi penyaringan udara pernapasan pada trachea. Proses induksi ini berulang dalam investigasi, analisis data dan penemuan pengetahuan baru pada jaringan yang lain yaitu jaringan ikat, jaringan otot dan jaringan saraf. Melalui tahapan inkuiri terbimbing pada siklus I dan II, keterampilan melakukan deduksi berkembang persentasenya menjadi $88,28 \%$ di akhir siklus II dari73,4\% pada siklus I.

\section{Argumentasi}

Keterampilan memberikan argumentasi terlatihkan pada setiap tahapan pembelajaran yaitu eksplorasi fenomena, fokus masalah dan rancangan investigasi. Ketika siswa melakukan investigasi, analisis data dan menemukan serta mengkomunikasikan pengetahuan baru, keterampilan argumentasi semakin banyak dikembangkan.

Pada siklus I, tahap eksplorasi fenomena menggulungnya daun jagung siswa mengeksporasi fenomena dengan memberikan argumen kemungkinan penyebab menggulungnya daun jagung dengan mengamati dan meraba struktur daun jagung. Tahap memfokuskan masalah siswa memberikan alternatif permasalahan yang akan dipecahkan salah satunya keterkaitan stuktur dan fungsi jaringan daun jagung terhadap menggulungnya daun jagung. Siswa mengemukakan alasan mengangkat permasalahan tersebut yaitu karena menggulungnya daun jagung sebagai salah satu organ tumbuhan kemungkinan dipengaruhi oleh karakteristik jaringannya sebagai penyusun organ daun. Kemungkinan terdapat suatu strktur tertentu pada jaringan daun jagung yang menyebabkan daun jagung menggulung berbeda dengan daun lainnya. Tahap perencanaan investigasi, siswa merancang informasi apa saja yang akan dikumpulkan untuk menganalisis permasalahan. Siswa dalam 1 kelompok memberikan argumen memilih mengumpulkan informasi yang dibutuhkan dan mereduksi informasi yang kurang relevan.

Tahap investigasi, analisis data dan penemuan pengetahuan baru, siswa berdiskusi dengan memberikan argumen struktur dan fungsi jaringan yang mempengaruhi fungsi organ yang disusun. Penemuan pengetahun baru disertai bukti pendukung adanya sel kipas pada jaringan epidermis daun jagung beserta fung-sinya yang berpengaruh dalam proses menggulungnya daun jagung. Tahap komunikasi merupakan tahapan yang melatih siswa berargumen begitu terbuka lebar. Tahap ini siswa dari kelompok lain terfasilitasi dalam memberikan tanggapan atas pengetahuan baru yang dikemukakan. Adu argumen antara pemateri dan peserta diskusi menjadikan pembelajaran semakin hidup. Siswa bebas mengemukakan pendapatnya disertai argumen.

Siswa mampu mengimprovisasi pegetahuan yang dimilikinya tentang otot lurik dan pengetahuan dan latihan otot mereka ketika fitnes dengan kegiatan melatih otot pada binaragawan yang diangkat dalam permasalahan pada siklus II. Pada fase investigasi dan analisis data siswa saling bertukar informasi dan saling memberikan argumentasi berdasarkan pengetahuan yang mereka miliki dalam menyelesaikan suatu permasalahan, maka keterampilan berpikir kritis siswa akan berkembang sehingga siswa dapat menentukan informasi dan pengetahuan yang benar dalam penyelesaian permasalah. Inkuiri terbimbing berkaitan sangat erat dengan keterampilan problem solving, kegiatan komunikasi dan petrukaran informasi berdasarkan logika berpikir disertai argumen (Qing, Jing, \& Yan, 2010). Tahapan inkuiri terbimbing mendorong siswa dalam tahap berdiskusi dan memberikan argumentasi secara kritis siswa melakui kelompok kecil maupun dalam diskusi besar di depan kelas (Greenwald \& Quitadamo, 2014). Keterampilan memberikan argumentasi mengalami pengembangan ke arah positif dari 74, 48\% pada siklus I menjadi $89,84 \%$ pada siklus II. 


\section{Evaluasi}

Pengembangan keterampilan evaluasi dilakukan sejak dari tahap perencanaan penelitian/investigasi hingga tahap mengkomunikasikan penemuan baru. Pada tahap perencanaan penelitian/investigasi, siswa melakukan analisis dan mengevaluasi informasi dan konsep tentang jaringan pada tumbuhan dan hewan yang benar agar dapat menentukan kesimpulan atau pemecahan masalah dengan benar. Pada saat tahap penelitian/investigasi siswa melakukan evaluasi dengan menilai kebenaran pendapat dan argumentasi teman dalam satu kelompok sehingga siswa dapat menentukan solusi yang tepat dalam pemecahan masalah keterkaitan struktur dan fungsi organ terhadap fungsi organ yang disusunnya. Hasil analisis data dan penemuan baru yang dilakukan kelompok lain dibandingkan dengan pengetahuan yang mereka miliki pada saat berkomunikasi untuk memperoleh pemecahan masalah disertai argumen yang tepat.

Siswa yang telah diperkenalkan keterampilan mengevaluasi pada siklus I, difokuskan untuk menyusun kerangka berpikir pada proses rancangan inventigasi untuk memfokuskan data/informasi apa saja yang diperlukan, apabila data/informasi dianggap kurang relevan disertai argumen yang jelas maka informasi tersebut direduksi. Pada siklus II, guru memberikkan instruksi dan pemodelan langsung pada tahap menganalisis kebenaran data fenomena jaringan epitel pada trachea memiliki karakteristik yang mendukung dengan fungsi trachea, guru memfasilitasi siswa melakukan latihan terbimbing bagaimana cara mengevaluasi pernyataan tersebut, dengan mengarahkan argumen yang disusun siswa. Guru memegang kendali dalam kelas dalam megarahkan argumen hanya terfokus struktur epitel, fungsi epitel dan fungsi trachea pada sistem pernapasan dan melakukan pengulangan. Tahap terakhir guru melakukan latihan bebas dengan mendesain aktivitas mengevaluasi pada tiga fenomena yang berbeda, yaitu tulang sebagai ja-ringan ikat, otot pada binaragawan yang kuat dengan massa otot yang besar dan terbentuk melalui latihan beban, serta kelainan akibat kerusakan jaringan saraf. Dari berbagai tahapan inkuiri terbimbing tersebut, memfasilitasi siswa berlatih keterampilan melakukan evaluasi sehingga meningkat dari $68,75 \%$ pada siklus I menjadi $81,64 \%$ pada siklus II.

Data peningkatan berpikir kritis menunjukkan indikator melakukan argumentasi mengalami peningkatan paling tinggi dibandingkan indikator yang lain yaitu sebesar 15,36\%. Tingginya peningkatan indikator berargumen tidak terlepas dari setiap tahap pembelajaran inkuiri yang melatihkan keterampilan melakukan argumentasi. Siswa diberikan kesempatan luas memberikan argumen pada tahap mengeksplorasi fenomena, memfokuskan masalaha, merancang dan melaksanakan penelitian/investigasi, menganalisis data dan mengonstruk pengetahuan baru dengan beradu argumen dengan siswa satu kelompok, serta mempertahankan argumen pada saat mengkomunikasikan pengetahuan baru.

Model inkuiri terbimbing memberikan latihan pada siswa untuk memcahkan masalah. Dalam proses pemecahan masalah siswa aktif dalam mencari dan saling memberikan pertukaran informasi, mengungkapkan argumentasi yang terkait dengan informasi yang digunakan dalam penyelesaian permasalahan (Slavin, 2005). Proses pengeksplorasian fenomena dan pemfoksan masalah memunculkan pertanyaan tentang menggulungnya daun jagung, jaringan ikat pada tulang ayam, dan jaringan otot binaragawan, siswa memberikan argumen terhadap pertanyaan yang diarahkan guru untuk mengeksplorasi fenomena dan menyusun rumusan masalah. Tahap merancang penelitian/investigasi, siswa mengemukakan argumen menggunakan bahan/preparat yang dipilih relevan atau tidak untuk menjawab pertanyaan. Siswa berdiskusi bersama kelompoknya dan saling memberikan argumen terkait informasi apa saja yang sesuai untuk menjawab permasalahan. Tahap investigasi dan analisis data, siswa memberikan beserta alasannya dalam memberikan sumbangan ide untuk mengkonstruk pengetahuan baru dari berbagai pengetahuan yang telah dimiliki. Tahap komunikasi merupakan tahapan yang paling memberi kesempatan siswa mengemukakan argumennya secara terbuka. Siswa saling adu argumen dalam presentasi, sanggahan dan tanggapan siswa silih berganti sehingga memaksa siswa untuk aktif mempertahankan, mendukung atau menolak hasil pengetahuan baru yang dipresentasikan disertai alasan yang relevan.

Model pembelajaran inkuiri terbimbing dapat melatih siswa untuk mempunyai pemikiran kritis. Inkuiri terbimbing merupakan model pembelajaran dengan pemberian latihan keterampilan berpikir kritis pada siswa (Saunders-Stewart, Shore., \& Gyles, 2012). Penguasaan langkah model pembelajaran inkuiri terbimbing, pengembangan keterampilan berikir kritis siswa didapatkan ide dalam rangka pemecahan permasalah yang ditemukan. Proses interaksi antar siswa yang terjadi dalam pembelajara inkuiri terbimbing menjadikan diperolehnya informasi, pengetahuan, konsep, cara pandang, dan pengalaman baru dalam menghadapi masalah nyata siswa. Pengetahuan baru yang ditemukan siswa akan dibandingkan dan dikonstruk dengan pengetahuan yang telah dimiliki siswa sehingga dapat menilai dan menentukan pendapat yang paling tepat untuk memecahkan permasalahan.

\section{SIMPULAN}

Implementasi model pembelajaran inkuiri terbimbing dapat merubah cara belajar siswa untuk berlatih berpikir tingkat tinggi melalui sintaks pembelajaran sehingga memberikan dampak mmengembangkan keterampilan berpikir kritis pada siswa di kelas XI IPA 1 SMA Negeri 2 Probolinggo. Tahapan mengobservasi fenomena memfokuskan masalah, merancang dan melakukan penelitian/investigasi, menganalisis data sampai ditemukannya pengetahuan baru menstimulasi perkembangan keterampilan berpikir kritis siswa. Diharapkan dilakukan pengkajian penerapan model pembelajaran inkuiri terbimbing untuk mengetahui pengaruh interaksi antar siswa terhadap keterampilan berpikir kritis dan sintaks inkuiri terbimbing. 


\section{DAFTAR RUJUKAN}

Ajwar, M., Prayitno, B. A., \& Sunarno, W. (2015). Pengaruh Pembelajaran Inkuiri Terbimbing dan Inkuiri Bebas Termodifikasi terhadap Prestasi Belajar Ditinjau dari Berpikir Kritis dan Kedisplinan Belajar Siswa Kelas X MIA SMA Negeri 8 Surakarta Tahun Pelajaran 2014/2015. Scientific Research and Essay, 4 (10), 1038-1046.

Andrini, V. S. (2016). The Effectiveness of Inquiry Learning Method to Enhance Students ' Learning Outcome : A Theoritical and Empirical Review, 7(3), 38-42.

Bilgin, I. (2009). The effects of guided inquiry instruction incorporating a cooperative learning approach on university students ' achievement of acid and bases concepts and attitude toward guided inquiry instruction. Scientific Research and Essay, 4(10), 1038-1046.

Chang, K., Sung, Y., \& Lee, C. (2003). Web-based collaborative inquiry learning. Journal of Computer Assisted Learning, 19, $56-69$.

Danisa, V. S., \& Dwiastuti, S. (2016). Pengaruh Model Guided Inquiry terhadap Kemampuan Berpikir Kritis pada Pembelajaran Biologi. Semnas Pendidikan Dan Saintek, 610-616.

Duron, R., Limbach, B., \& Waugh, W. (2006). Critical Thinking Framework For Any Discipline. International Journal of Teaching and Learning in Higher Education, 17(2), 160-166.

Greenwald, R. R., \& Quitadamo, I. J. (2014). A Mind of Their Own: Using Inquiry Based Teaching to Build Critical Thinking Skills and Intelectual Engagement in an Undergraduate Neuroanatomy Course. The Journal of Undergraduate Neuroscience Education, 12 (2), A100-A106.

Joyce. \& Shower. (2009). Models of Teaching Fourth Edition. Massa Chusettes: Allymand and Bacon Publishing Company. Julianto, S. (2011). Teori dan Implementasi model-model Pembelajaran Inovatif. Surabaya.: UNESA.

Kevin, M. L. . (2004). A Comparison of Inquiry and Worked Example WebBased Instruction Using Physlets. Journal of Science Education and Technology.

Kuhlthau, C. C. (2010). Guided Inquiry: School Libraries in the 21 st Century. School Worldwide, 16(1), 17-27.

Lawson, A. E. (2000). The Generality of Hypotetico-deductive Reasoning; Making Scientific Thinking Explicit. The American Biology Teacher, 62(7), 482-495.

Masitoh, I. D., \& Ariyanto, J. (2017). Pengaruh Model Pembelajaran Inkuiri Terbimbing terhadap Kemampuan Berpikir Kritis Siswa Kelas X MIA pada Materi Pencemaran Lingkungan di Surakarta The Influence of Guided Inquiry Learning Toward Critical Thinking Skills of X MIA Students on Environtmental. Bioedukasi, 10(1), 71-79.

Minner, D. D. (2009). Inquiry-Based Science Instruction-What Is It and Does It Matter? Results from a Research Synthesis Years 1984 to 2002. Journal of Research in Science Teaching, 47(1), 474-496.

Natalina, M., Mahadi, I., \& Suzane, A. C. (2013). Penerapan Model Pembelajaran Inkuiri Terbimbing (Guided Inquiry) untuk Meningkatkan Sikap Ilmiah dan Hasil Belajar Biologi Siswa Kelas XI IPA5 SMA Negeri 5 Pekanbau Tahun Ajaran 2011/2012. Semirata, 83-92.

Nurroyani, I. S., Dwiastuti, S., \& Karyanto, P. (2015). Pengaruh Model Inkuiri Terbimbing terhadap Hasil Belajar Biologi Siswa Kelas XI IPA SMA Negeri 2 Sukoharjo Tahun Pelajaran 2013/2014. Jurnal Pendidikan Biologi, 7(2), 94-101.

Perdani, W. S. R., Santosa, S., Ramli, M., \& Martono, Y. E. (2015). Peningkatan Kemampuan Berpikir Kritis dengan Model Inkuiri pada Materi Sistem Indera Kelas XI MIA 6 SMA N 4 Surakarta Tahun Pelajaran 2014/2015. Seminar Nasional XII Pendidikan Biologi FKIP UNS 2015, 260-264.

Qing, Z., Jing, G., \& Yan, W. (2010). Promoting preservice teachers ' critical thinking skills by inquiry-based chemical experiment. Procedia Social and Behavioral Sciences, 2(2), 4597-4603.

Rahmah, A., Lesmanawati, I. R., \& Wahidin. (2015). Penerapan Model Pembelajaran Inkuiri Terbimbing untuk Meningkatkan Keterampilan Berpikir Kritis Siswa pada Pokok Bahasan Ekosistem Kelas X di SMA Negeri 1 Krangkeng. Scientific Education, 4(1), 1-7.

Retnosari, N., Susilo, H., \& Suwono, H. (2016). Pengaruh Model Pembelajaran Inkuiri Terbimbing Berbantuan Multimedia Interaktif terhadap Berpikir Kritis Siswa Kelas XI SMA Negeri di Bojonegoro. Jurnal Pendidikan, (Teori, Penelitian, dan Pengembangan), 1529-1535.

Sanjaya, W. (2007). Strategi Pembelajaran Berorientasi Standart Proses Pendidikan. Jalarta: Kencana Prenada Media.

Saunders-Stewart, Shore., \& Gyles. (2012). Student Outcomes in Inquiry Instruction: A Literature-Derived Inventory. Journal of Advanced Academics, 5(1), 76-84.

Slavin, R. E. (2005). Cooperative Learning Teori, Riset, dan Praktik. Terjemahan oleh Nalurita Yusron. Nusa Media.

Tan, K. C. D., \& Kim, M. . (2012). Issues and Challenges in Science Education Research. New York: Springer Dordrecht Heidelberg New York London.

William, M. B. (2010). The Measurement and Teaching of Critical Thingking Skills. University of Minnesot.

Zubaidah, S. (2017). Berpikir Kritis: Kemampuan Berpikir Tingkat Tinggi yang Dapat Dikembangkan melalui Pembelajaran Sains. Pendidikan Biologi, 2(1), 56-63. 